\title{
血液透析患者におけるレストレスレッグス症候群と 生命予後の関連
}

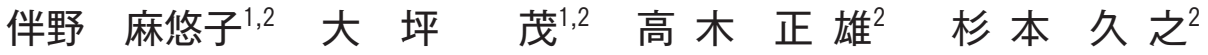 \\ 新田 孝 作 ${ }^{1}$ \\ 1東京女子医科大学第四内科 ${ }^{2}$ 三軒茶屋病院内科
}

キーワード：血液透析, 周期性四肢運動, 生命予後, レストレスレッグス症候群

〈要旨〉

血液透析患者において RLS と生命予後の関連について検討した．当院の維持血液透析患者でRLSの問診をしえた 67 例を対象とし, 生命予後に対する危険因子の解析を施行した。 RLS と診断した患者は 10 例で, 有病率は $14.9 \%$, 平均観察期間は $3.2 \pm 1.0$ 年であった. RLSの全死因による死亡に対するリスク比は $1.79(95 \% \mathrm{Cl} 1.07-2.84, p=$ 0.030) で，心血管病による死亡に対するリスク比は 2.97 (95\% Cl 1.52-5.99, p=0.002) であった. 血清クレアチ 二ン值, 糖尿病性腎症の有無, 心血管病の合併の有無およびRLS の有無での多変量解析において, RLS はリスク比 $1.72 （ 95 \%$ Cl 1.02-2.73, p=0.044）と，己れらの因子とは独立した死亡のリスク因子であった. わが国の単一施設 での血液透析患者において, RLS は全死因, 特に心血管病による死亡の危険因子であった.

\section{Relationship between restless legs syndrome and mortality in hemodialy- sis patients}

\author{
Mayuko Banno ${ }^{1,2}$, Shigeru Otsubo ${ }^{1,2}$, Masao Takagi $^{2}$, Hisayuki Sugimoto ${ }^{2}$, Kosaku Nitta $^{1}$ \\ ${ }^{1}$ Department of Medicine, Kidney Center, Tokyo Women's Medical University, ${ }^{2}$ Sangenjaya Hospital
}

Key words : hemodialysis, mortality, periodic limb movement, restless legs syndrome

$\langle$ Abstract〉

Restless legs syndrome (RLS) is a sensorimotor neurological disorder characterized by paresthesia, dysesthesia and the irresistible urge to move the legs, especially at night. Its prevalence is much higher among dialysis patients than in the general public. RLS is known to be associated with depression and quality of life. Recently, the association between the severity of RLS and the risk of new cardiovascular events in hemodialysis patients was also reported. In this study, we examined the relationship between RLS and mortality in hemodialysis patients. A total of 67 patients receiving maintenance hemodialysis at Sangenjaya Hospital were enrolled in this study. Clinical data, including age, gender, duration of hemodialysis therapy, complication of cardiovascular disease and cause of end-stage kidney disease, were collected. The clinical follow-up data were obtained from the hospital records. The clinical endpoints were defined as death from any cause and cardiovascular death. Cox proportional hazards model for predictors of survival was examined. RLS affected $14.9 \%$ of the study population. The mean observation period was $3.2 \pm 1.0$ years. During the follow-up period, 20 deaths were recorded. In univariate regression analysis, the hazard ratio (HR) of patients with RLS was $1.79(95 \% \mathrm{Cl} 1.07-2.84, p=0.030)$ for all-cause death and 2.97 (95\% Cl 1.52-5.99, $\mathrm{p}=0.002$ ) for cardiovascular death. Multivariate Cox analysis, which included creatinine, presence of diabetic nephropathy and presence of cardiovascular disease, identified RLS as an independent predictor of mortality ( HR 1.72, 95\% Cl 1.02-2.73, $p=0.044$ ). RLS was a risk factor for mortality, especially for cardiovascular death, and acted independently of other risk factors, including creatinine, presence of diabetic nephropathy and presence of cardiovascular disease in Japanese single-unit hemodialysis patients.

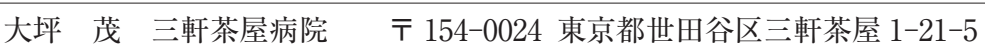

Shigeru Otsubo Tel :03-3410-7321 Fax :03-3410-7325 E-mail : sotsubo@hb.tp1.jp

〔受付日：2014 年 7 月 4 日, 受理日：2014 年 11 月 6 日〕 


\section{はじめに}

レストレスレッグス症候群（restless legs syndrome : RLS) は脚に不快な感覚が現れて脚をじっと していられなくなることを特徴とする疾患である.夕 方から夜間にかけて症状が強まるためしばしば不眠の 原因となり，仕事や生活に支障をきたすこともある. RLS は血液透析患者に高率に合併し，うつや睡眠障害 と関連することが報告されている ${ }^{1,2)}$.さらに血液透析 患者において, RLS は心血管病の新規発症ならびに死 亡率にも関連することがイタリアより報告されてい る ${ }^{3)}$. 今回われわれは, わが国の単一施設における血 液透析患者を対象に RLS と生命予後の関連について 検討した。

\section{I . 対象と方法}

当院の維持透析患者で 2010 年 7 月から 8 月の間に RLSの問診をしえた 67 例を対象とした。透析方法は 67 例中 6 例で血液濾過透析, ほかの 61 例で血液透析 であった。患者背景 (年齢, 透析歴, 慢性腎臓病の原 疾患, 心血管病（脳血管，末梢血管も含む）の合併の 有無), 問診時の週初めの透析前の生化学, 血算值を調 ベた. KT/Vを single pool modelの簡易式で, normalized protein catabolic rate (nPCR) を Depner らの 式4で計算した. International Restless Legs Syndrome Study Group の 4 項目（1. 脚の異常感覚によ り脚を動かしたくてたまらない衝動感と不快感, 2. 休 んでいたり,じっとしていると悪化, 3. 脚の運動によ り軽減ないし消失, 4 . 夕方から夜に出現ないし悪 化 $)^{5)}$ をずて満たし, ほかの睡眠障害, 身体疾患や神 経疾患, 精神疾患, 薬物使用では説明できない症例を RLS と診断した， RLSの有無で 2 群に分け，患者背 景, 検査結果を比較した. データは平均 $\pm \mathrm{SD}$ で示し, 連続変数の比較にはスチューデントの $\mathrm{t}$ 検定を使用し た.カテゴリの比較には $\chi$ 二乗検定を使用した. 問診 時を観察開始日とし，2014 年 6 月までの期間ですべて の死因，ならびに心血管病による生命予後をエンドポ イントとし, 生命予後と患者背景, 臨床検査所見との 関連をコックス比例ハザードモデルにより検討した. 全死因による生命予後に対する多変量解析は, 単変量 解析にて $\mathrm{p}$ 值が低值 $(\mathrm{p}<0.3)$ であった 4 因子, 血清 クレアチニン值, 糖尿病性腎症の有無, 心血管病合併 の有無, RLSの有無で施行した. RLS の有無で 2 群に 分け生命予後をカプランマイヤー法で評価し， ログラ
ンク検定で比較した．解析は JMP 5.1 を使用し, p 值 0.05 未満を有意とした。

\section{II. 結 果}

表 1 に患者背景を示した. RLS と診断した患者は 10 例で，有病率は $14.9 \%$ であった。 女性の占める割合は RLS 群において $30.0 \%$, RLS なし群では 35.1\%で両群 において性差は認めなかった。 女性 23 例中 22 例が閉 経していた. 年齢, 透析歴にも有意差は認めなかった. 心血管病の合併はRLS 群で $70.0 \%$ に対し, RLSなし群 では $45.6 \%$ RLS群で高い傾向を示したが有意ではな かった $(\mathrm{p}=0.155)$. 平均観察期間は $3.2 \pm 1.0$ 年で観察 期間中 20 例に死亡を認めた. RLS 群では 10 例中 6 例 (60.0\%) において死亡を認めたのに対し, RLS なし群 では 57 例中 14 例 $(24.8 \%)$ で, RLS 群において死亡 率が高值であった $(\mathrm{p}=0.024)$ ．RLS 群において死因は 感染症が 1 例, 心不全が 2 例, 心筋梗塞が 1 例, 脳血 管障害が 1 例, 腫瘍が 1 例であり, RLS なし群におい ては, 感染症が 10 例, 心不全が 2 例, 脳血管障害が 2 例であった。 心血管病による死亡は RLS 群では 10 例 中 4 例 $(40.0 \%)$ であったのに対し RLS なし群では 57 例中 4 例 $(28.6 \%)$ であり，RLS 群で心血管関連死が 有意に高率であった $(\mathrm{p}=0.012)$. アルブミンは RLS 群 で $3.8 \pm 0.3 \mathrm{~g} / \mathrm{dL}$ に対し RLSなし群では $4.0 \pm 0.2 \mathrm{~g} / \mathrm{dL}$ と RLS 群で低值であった $(\mathrm{p}=0.015) . n P C R$ は RLS 群で低い傾向を示したが有意ではなかった（ $\mathrm{p}=$ 0.107). その他, トランスフェリン飽和度やフェリチ ンを含め検索した中で有意差を示したものは認めな かった。

図 1 にRLS群となし群のそれぞれの生存曲線を示し た. 最大観察期間は 3.9 年で 3 年後の生存率は RLS 群 で $50.0 \%$, RLS なし群で $83.4 \%$ と RLS 群で有意に生存 率が低值であった $(\mathrm{p}=0.012)$.

表 2 に死亡に対するコックス比例ハザード分析を示 した．単変量解析において RLSの全死因に対するリス ク比は 1.79 (95\% CI 1.07-2.84, p=0.030）であった. RLS の心血管病による死亡に対するリスク比は 2.97 （95\% CI 1.52-5.99, p=0.002）であった. 単変量解析 で $\mathrm{p}$ 值 0.3 未満であった血清クレアチニン值, 糖尿病 性腎症の有無および心血管病の合併の有無を含む多変 量での解析でも RLSを有することはリスク比 1.72 (95\% CI 1.02-2.73, p=0.044) と, これらの因子とは 独立した死亡のリスク因子であった（表 3). 
表 1 Background characteristics of the study participants

\begin{tabular}{|c|c|c|c|}
\hline & With RLS $(n=10)$ & Without RLS $(n=57)$ & $\mathrm{P}$ value \\
\hline Gender $(\mathrm{M} / \mathrm{F})$ & $7 / 3$ & $37 / 20$ & NS \\
\hline Age (year) & $65.6 \pm 12.6$ & $65.3 \pm 12.4$ & NS \\
\hline Duration of HD (year) & $16.5 \pm 14.8$ & $15.6 \pm 13.3$ & NS \\
\hline Cardiovascular disease $\mathrm{n}(\%)$ & $7(70.0)$ & $26(45.6)$ & NS \\
\hline \multicolumn{4}{|l|}{ Primary cause of ESKD, n (\%) } \\
\hline Chronic glomerulonephritis & $5(50.0)$ & $32(56.1)$ & \\
\hline Diabetic nephropathy & $4(40.0)$ & $13(22.8)$ & \\
\hline Nephrosclerosis & $0(0.0)$ & $4(0.7)$ & \\
\hline Unknown and others & $1(10.0)$ & $8(14.0)$ & \\
\hline Death n (\%) & $6(60.0)$ & $14(24.6)$ & 0.024 \\
\hline Cardiovascular related death $\mathrm{n}(\%)$ & $4(40.0)$ & $4(7.0)$ & 0.003 \\
\hline Total protein $(\mathrm{g} / \mathrm{dL})$ & $6.8 \pm 0.6$ & $6.9 \pm 0.4$ & NS \\
\hline Albumin $(\mathrm{g} / \mathrm{dL})$ & $3.8 \pm 0.3$ & $4.0 \pm 0.2$ & 0.015 \\
\hline Creatinine $(\mathrm{mg} / \mathrm{dL})$ & $9.72 \pm 1.82$ & $10.83 \pm 2.77$ & NS \\
\hline Calcium (mg/dL) & $9.0 \pm 0.5$ & $9.3 \pm 0.5$ & NS \\
\hline Phosphate $(\mathrm{mg} / \mathrm{dL})$ & $5.5 \pm 1.1$ & $5.6 \pm 1.1$ & NS \\
\hline Iron $(\mathrm{mg} / \mathrm{dL})$ & $68 \pm 27$ & $52 \pm 17$ & NS \\
\hline Total iron-binding capacity $(\mathrm{mg} / \mathrm{dL})$ & $269 \pm 33$ & $270 \pm 46$ & NS \\
\hline Transferrin saturation & $0.20 \pm 0.08$ & $0.26 \pm 0.12$ & NS \\
\hline Total-cholesterol $(\mathrm{mg} / \mathrm{dL})$ & $174 \pm 47$ & $160 \pm 33$ & NS \\
\hline Triglyceride $(\mathrm{mg} / \mathrm{dL})$ & $127 \pm 99$ & $110 \pm 69$ & NS \\
\hline Ferritin $(\mathrm{ng} / \mathrm{mL})$ & $148 \pm 114$ & $148 \pm 111$ & NS \\
\hline Intact parathyroid hormone $(\mathrm{pg} / \mathrm{dL})$ & $217 \pm 157$ & $249 \pm 158$ & NS \\
\hline C-reactive protein $(\mathrm{mg} / \mathrm{dL})$ & $0.21 \pm 0.13$ & $0.21 \pm 0.21$ & NS \\
\hline White blood cells count $(/ \mathrm{mL})$ & $5,840 \pm 2,511$ & $5,842 \pm 1,805$ & NS \\
\hline Hemoglobin $(\mathrm{g} / \mathrm{dL})$ & $10.6 \pm 1.6$ & $10.6 \pm 1.0$ & NS \\
\hline Platelet count $\left(\times 10^{4} / \mathrm{mL}\right)$ & $16.5 \pm 7.6$ & $18.8 \pm 6.2$ & NS \\
\hline $\mathrm{KT} / \mathrm{V}$ & $1.30 \pm 0.35$ & $1.39 \pm 0.23$ & NS \\
\hline nPCR (g/kg/day) & $0.96 \pm 0.14$ & $1.06 \pm 0.18$ & NS \\
\hline
\end{tabular}

Values are shown as mean \pm SD.

RLS : restless legs syndrome, HD : hemodialysis, ESKD : end-stage kidney disease, nPCR : normalized protein catabolic rate

\section{III. 考察}

わが国の単一施設での血液透析患者を対象に, RLS の有病率が $14.9 \%$ と高率であることを確認した。ま た，RLSは血清クレアチニン值，糖尿病性腎症の有 無, 心血管病の合併の有無といったほかの因子とは独 立した生命予後に対する危険因子であった。

RLS の有病率は欧米では 5〜10\%と報告され，男性 より女性に多く, また加齢とともに増加傾向にある ${ }^{6)}$. わが国での RLSの一般人口での有病率は概ね $4 \%$ と報 告されている7 . 血液透析を導入した患者においては, $23.0 \%$ と高率な合併が報告されている 検討でも $14.9 \%$ と比較的高率に RLS の患者を認めた. わが国の検討にても女性に多いとの報告がある ${ }^{9)}$ が, 今回の検討では症例が少ないためか性差は認めなかっ た. RLSは散発的に生じるが，半数以上の RLS 患者に 常染色体優性の家族的発現が認められ，RLS を有する

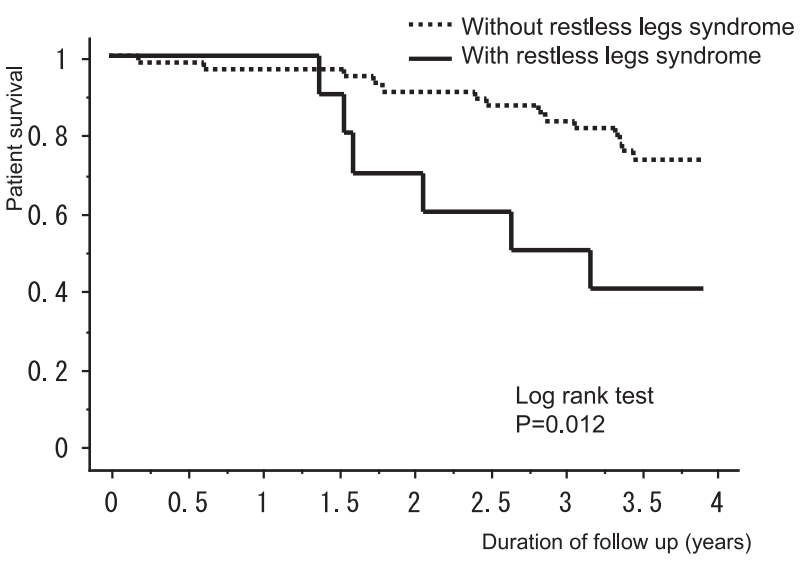

図 1 Comparison of survival probabilities between with restless legs syndrome group and without restless legs syndrome group

患者は RLS のない人に比べ，一親等の血族に 3〜 6 倍 RLSが合併しやすいといわれている10). RLS の病因と して, 視床下部後部ドパミン作動性細胞群（A11 神経 細胞群）の機能低下が報告されている ${ }^{11)}$ 。後角に対す 
表 2 Cox proportional hazards analysis of the covariates for all cause of death (simple analysis)

\begin{tabular}{lcc}
\hline & Hazard ratio $(95 \% \mathrm{CI})$ & P value \\
\hline Age (per year) & $1.01(0.98-1.05)$ & 0.508 \\
HD duration (per year) & $1.01(0.98-1.05)$ & 0.433 \\
Total protein (per g/dL) & $1.03(0.37-2.78)$ & 0.959 \\
Albumin (per g/dL) & $0.80(0.14-4.44)$ & 0.804 \\
Creatinine (per mg/dL) & $0.88(0.75-1.04)$ & 0.133 \\
Calcium (per mg/dL) & $0.73(0.34-1.65)$ & 0.446 \\
Phosphate (per mg/dL) & $1.06(0.69-1.57)$ & 0.780 \\
Iron (per $\mu$ g/dL) & $1.00(0.98-1.02)$ & 0.915 \\
Transferrin saturation (per 1) & $2.25(0.03-96.56)$ & 0.702 \\
Ferritin (per ng/mL) & $1.00(1.00-1.01)$ & 0.502 \\
Total-cholesterol (per mg/dL) & $1.00(0.99-1.01)$ & 0.610 \\
Triglyceride (per mg/dL) & $1.00(0.99-1.01)$ & 0.886 \\
Intact parathyroid hormone (per pg/dL) & $1.00(1.00-1.00)$ & 0.673 \\
C-reactive protein (per mg/dL) & $1.65(0.17-7.98)$ & 0.617 \\
Hemoglobin (per g/dL) & $1.04(0.67-1.52)$ & 0.851 \\
KT/V (per 1) & $1.23(0.19-7.45)$ & 0.826 \\
nPCR (per g/kg/day) & $0.66(0.05-7.37)$ & 0.744 \\
Diabetic nephropathy (Y) & $1.29(0.79-2.01)$ & 0.298 \\
Cardiovascular disease (Y) & $1.66(1.05-2.79)$ & 0.029 \\
Restless legs syndrome (Y) & $1.79(1.07-2.84)$ & 0.030 \\
\hline
\end{tabular}

HD : hemodialysis, nPCR : normalized protein catabolic rate

表 3 Cox proportional hazards analysis of the covariates for all cause of death (Multiple analysis)

\begin{tabular}{lcc}
\hline & Hazard ratio $(95 \% \mathrm{CI})$ & $\mathrm{P}$ value \\
\hline Creatinine (per mg/dL) & $0.93(0.78-1.12)$ & 0.455 \\
Diabetic nephropathy $(\mathrm{Y})$ & $1.09(0.66-1.73)$ & 0.708 \\
Cardiovascular disease $(\mathrm{Y})$ & $1.54(0.95-2.64)$ & 0.079 \\
Restless legs syndrome $(\mathrm{Y})$ & $1.72(1.02-2.73)$ & 0.044 \\
\hline
\end{tabular}

る A11 神経細胞群によるドパミン調節が障害される ことで，感覚入力の脱抑制が生じ，その結果「むずむ ず感」といった異常な筋知覚が生じると考えられてい る ${ }^{12)}$. 一方, 脊髄では A11 神経細胞群からのドパミン 投射が，中間外側核の交感神経節前神経に直接的な抑 制作用を有している ${ }^{13)}$. RLS において交感神経出力が 増大すると, 副腎からアドレナリンが放出される14). 交感神経刺激により筋紡錘活動が立進し, 周期性四肢 運動（periodic limb movement：PLM）という筋緊 張，不随意運動をひき起こす ${ }^{11)}$. 同時にそうした運動 は間接的に筋肉の痛み・異常感覚をひき起こす ${ }^{14)}$. RLS の患者の 80〜 90\%に睡眠時周期性四肢運動 (periodic limb movement during sleep : PLMS) が認めら れる ${ }^{15)}$. 非侵襲的, 連続的な血圧, 脈拍モニターを使 用した研究で, PLMS は血圧, 脈拍の上昇を伴うこと が示された ${ }^{16)}$. PLMSは, 交感神経活動の立進と関連 し, 高血圧, 心疾患, 脳血管障害などに関わると報告 されている ${ }^{17)}$. RLSにおいても同様に視床下部-下垂
体-副腎系，交感神経系の活性化により心血管病と関 連すると考えられている17,18). Sleep Heart Health Study によると, RLS を有する患者は, RLSのない対 象と比較し, 冠動脈疾患と心血管疾患の罹患リスクが 約 2 倍であった ${ }^{19)}$. 今回の研究において, 脈拍や血圧 に関しては評価できなかったが, RLS 群は心血管病の 合併が多い傾向を示し, 心血管病による死亡は RLS 群 において有意に高率であった. RLS は約 3 年の生命予 後に関しリスク比 1.87 であった，死因を心血管病に限 定すると,リスク比 2.97 とさらに上昇した。

一方, RLSの発症において, 中枢神経系の鉄不足に よる脳内のドパミン合成障害が関与するという，鉄・ ドパミン仮説が報告されている ${ }^{20)}$ 。脳内においてドパ ミンはチロシンより合成されるが，その律速酵素の tyrosine hydroxylase の補酵素として鉄は作用し，鉄 不足や利用障害はドパミン合成の抑制を介して RLS 発症に関与する ${ }^{20)}$ 。透析患者 1,130 例を対象とした研 究において, RLS 群はRLSなし群に比較してフェリチ ンが低值であることが報告されている ${ }^{21)}$.われわれの 検討では症例数が少なかったためか, RLS 群と RLSな し群ではフェリチンやトランスフェリン飽和度に有意 差は認めなかった.

今回，われわれの検討において RLS 群において血清

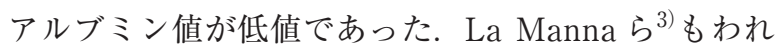
われと同様に RLS 群におけるアルブミン低值を報告 しており，低栄養状態と RLS 症候群の間に鉄欠乏の関 


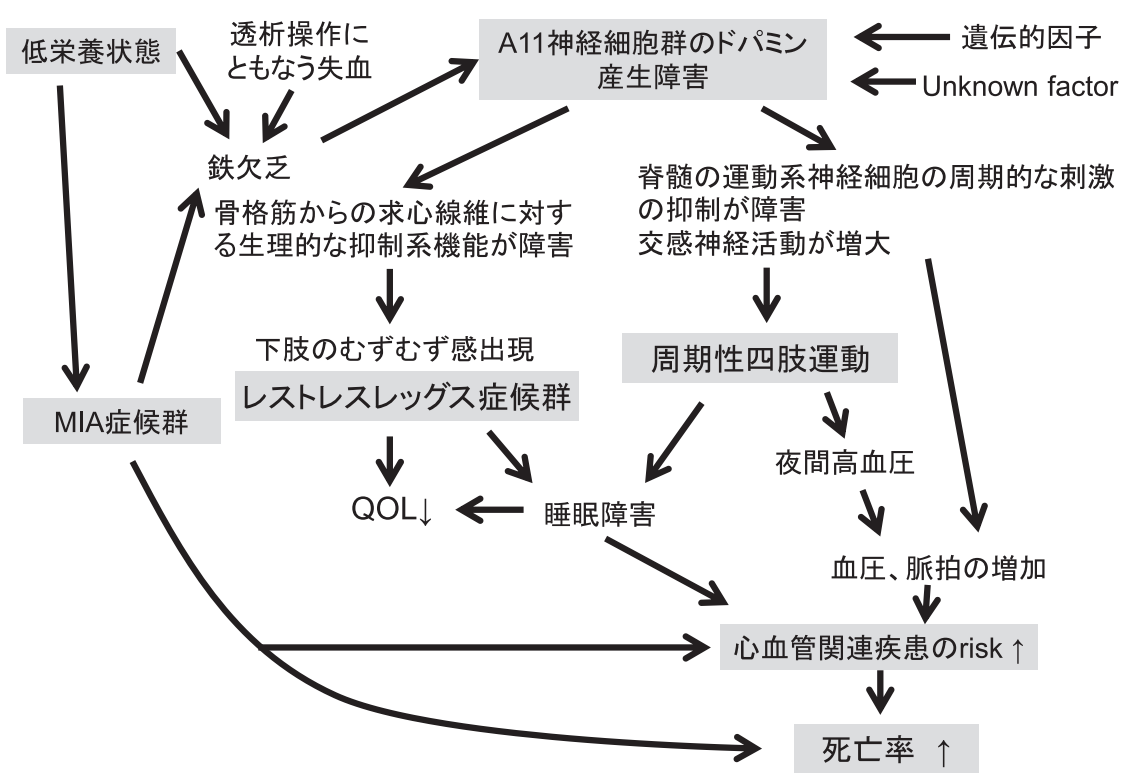

図 2 Hypothesis of relationship between restless legs syndrome and mortality MIA : malnutrition-inflammation-atherosclerosis QOL : quality of life

与など, 何らかの関係が示唆される.nPCR は症例数 が少ないためか両群間で有意差には至らなかったが, RLS 群で低い傾向を示した.

Sleep Heart Health Study によると，RLS を有する 患者はRLSを有さない患者と比し, 入眠障害, 中途覚 醒，早朝覚醒といった睡眠障害を高率に認めた222。 今 回の研究において, 睡眠導入薬の使用など, 睡眠につ いての検討はデータ欠損のためできなかった．睡眠障 害は生命予後を悪化させるといわれている23). さら に, SF-36による生活の質の調査で, RLS の患者では 一般住民の健常者に比べ身体的役割，疼痛，活気を中 心に全般的な生活の質の低下がみられ，2 型糖尿病や うつ病と同様の生活の質であることがいわれている6 ${ }^{6}$.

以上のまとめとして, RLS と生命予後との関連の仮 説を図 2 に示した．低栄養状態に伴う鉄摂取不足や， 透析操作に伴う失血などによる鉄欠そ状態はドパミン 代謝障害をひき起こす。こうした鉄欠そ状態や，遺伝 的あるいは何らかの因子による A11 細胞群における ドパミン産生障害は，求心線維に対する生理的な抑制 系の障害をきたし，下肢むずむず感の出現，RLS の発 症へとつながっていく，一方, A11 細胞群でのドパミ ン不足は交感神経系の活動を抑制しきれず，PLMを ひき起こす，交感神経活動の増加や PLM は血圧, 脈 拍の増加をひき起こし, 心血管病につながる. 一方, RLS，PLM は睡眠障害をひき起こし，同様に心血管病 を発症ないしは増悪させ，心血管病は生命予後を悪化 させる．RLSはうつや QOL の低下もひき起こす，さ らに, RLS と関連のありうる低栄養状態は malnutri-
tion-inflammation-atherosclerosis（MIA）症候群と関 連し生命予後を不良にする。

血液透析患者に打いて, イタリアより, RLS と死亡 率との関連がすでに報告されている゙)。また，アメリ カ合衆国より同様に血液透析患者において, RLS の患 者の中でもより重症度の重い患者群のほうがより生命 予後が悪いという報告もなされている24). RLS の治療 は QOL の改善のみならず, 生命予後の改善にも関与 する可能性がある.

本研究の限界として, 単一施設での検討であるこ と, 症例数が少ないことがあげられる. 血圧や脈拍, 鉄剤の影響, 睡眠導入薬の有無など睡眠との関連や RLS に対する治療の影響は欠損值があり今回評価で きなかった，性別，フェリチン，血液滤過透析と血液 透析の違い，透析効率の影響などを含めより多くの症 例による検討が必要である。

上記のごとく, 海外の検討ではRLS と生命予後の関 連がすでに報告されている3 ${ }^{3,24)}$ ，単一施設の検討では あるが，人種差を超えてわが国の透析患者でもこうし たRLS と生命予後との関連を認めた点は意義深いと 考える.

\section{文献}

1) Araujo SM, de Bruin VM, Nepomuceno LA, et al. Restless legs syndrome in end-stage renal disease: Clinical characteristics and associated comorbidities. Sleep Med 2010; 11: 785-90.

2) Tuncel D, Orhan FO, Sayarlioglu H, Isı IO, Utku U, 
Dinc A. Restless legs syndrome in hemodialysis patients: association with depression and quality of life. Sleep Breath 2011; 15: 311-5.

3) La Manna G, Pizza F, Persici E, et al. Restless legs syndrome enhances cardiovascular risk and mortality in patients with end-stage kidney disease undergoing long-term haemodialysis treatment. Nephrol Dial Transplant 2011; 26: 1976-83.

4) Depner TA, Daugirdas JT. Equations for normalized protein catabolic rate based on two-point modeling of hemodialysis urea kinetics. J Am Soc Nephrol 1996; 7: 780-5.

5) Allen RP, Picchietti D, Hening WA, Trenkwalder C, Walters AS, Montplaisi J. Restless Legs Syndrome Diagnosis and Epidemiology workshop at the National Institutes of Health; International Restless Legs Syndrome Study Group Restless legs syndrome: diagnostic criteria, special considerations, and epidemiology. A report from the restless legs syndrome diagnosis and epidemiology workshop at the National Institutes of Health. Sleep Med 2003; 4: 101-19.

6) Allen RP, Walters AS, Montplaisir J, et al. Restless legs syndrome prevalence and impact REST general population study. Arch Intern Med 2005; 165: 1286-92.

7) Nomura T, Inoue $Y$, Kusumi M, Uemura Y, Nakashima $\mathrm{K}$. Prevalence of restless legs syndrome in a rural community in Japan. Mov Disord 2008; 23: 2363-9.

8) Kawauchi $A$, Inoue $Y$, Hashimoto $T$, et al. Restless legs syndrome in hemodialysis patients: healthrelated quality of life and laboratory data analysis. Clin Nephrol 2006； 66：440-6.

9）黑田健治，和田大和．レストレスレッグ症候群の疫学 と臨床的特徵. 臨精薬理 2012；15：461-8.

10) Jack CR Jr, Knopman DS, Jagust WJ, et al. Hypothetical model of dynamic biomarkers of the Alzheimer's pathological cascade. Lancet Neurol 2010； 9: 119-28.

11）黑岩義之, 平田幸一, 野村哲志, 他. 標準的神経治療 Restless legs 症候群．神経治療 2012；29：71-109.

12）平田幸一, 鈴木圭輔. Restless legs 症候群の診断と新 規治療法 病態生理と診断 BRAIN and NERVE. 神研 の進歩 2013；65：1185-97.

13) Gladwell SJ, Coote JH. Inhibitory and indirect excit- atory effects of dopamine on sympathetic preganglionic neurons in the neonatal rat spinal cord in vitro. Brain Res 1999; 818: 397-407.

14) Barker D, Saito M. Autonomic innervation of receptors and muscle fibers in cat skeletal muscle. Proc R Soc Lond B Biol Sci 1981；212: 317-32.

15）米国睡眠医学会. 周期性四肢運動障害. 日本睡眠学会 診断分類委員会訳. 睡眠障害国際分類, 第 2 版, 診断 とコードの手引．東京：医学書院，2010；192-5.

16) Pennestri MH, Montplaisir J, Fradette L, Lavigne G, Colombo R, Lanfranchi PA. Blood pressure changes associated with periodic leg movements during sleep in healthy subjects. Sleep Med 2013; 14: 555-61.

17) Walters AS, Rye DB. Review of the relationship of restless legs syndrome and periodic limb movements in sleep to hypertension, heart disease, and stroke. Sleep 2009; 32: 589-97.

18) Schilling C, Schredl M, Strobl P, Deuschle M. Restless legs syndrome: evidence for nocturnal hypothalamic-pituitary-adrenal system activation. Mov Discord 2010; 25: 1047-52.

19) Winkelman JW, Shahar E, Sharief I, Gottlieb DJ. Association of restless legs syndrome and cardiovascular disease in the Sleep Heart Health Study. Neurology 2008; 70: 35-42.

20) Clemens S, Rye D, Hochman S. Restless legs syndrome: revisiting the dopamine hypothesis from the spinal cord perspective. Neurology 2006; 67: 12530.

21) Lin $\mathrm{CH}, \mathrm{Wu} \mathrm{VC}$, Li WY, et al. Restless legs syndrome in end-stage renal disease: a multicenter study in Taiwan. Eur J Neurol 2013; 20：1025-31.

22) Budhiraja P, Budhiraja R, Goodwin JL, et al. Incidence of restless legs syndrome and its correlates. J Clin Sleep Med 2012; 8: 119-24.

23) Sterniczuk R, Theou O, Rusak B, Rockwood K. Sleep disturbance is associated with incident dementia and mortality. Curr Alzheimer Res 2013; 10: 767-75.

24) Unruh ML, Levey AS, D’Ambrosio C, et al. Restless legs symptoms among incident dialysis patients: association with lower quality of life and shorter survival. Am J Kidney Dis 2004; 43: 900-9. 